\title{
Cutaneous Liposarcoma
}

National Cancer Institute

\section{Source}

National Cancer Institute. Cutaneous Liposarcoma. NCI Thesaurus. Code C5615.

A malignant adipose tissue neoplasm of the skin. 